\title{
Evaluation of Inhibition Effects of Some Cardiovascular Therapeutics on Human Erythrocyte Carbonic Anhydrase Isoenzymes
}

\author{
Namık KILINÇ ${ }^{1 *}$, Zuhal ALIM², Bülent ŞENGÜL ${ }^{3}$, Mehmet Mustafa İSGÖR ${ }^{4}$, Şükrü \\ BEYDEMIR $^{5}$ \\ ${ }^{l}$ Iğdır University, Vocational School of Health Service, Department of Medical Services and Techniques, Igdir, \\ Turkey \\ ${ }^{2}$ Ahi Evran University, Faculty of Science and Arts, Department of Chemistry, Kirsehir, Turkey \\ ${ }^{3}$ Bayburt University, Vocational School of Health Service, Department of Health Care Service, Bayburt, Turkey \\ ${ }^{4}$ Mustafa Kemal University, Faculty of Veterinary Sciences, Department of Biochemistry, Hatay, Turkey \\ ${ }^{5}$ Anadolu University, Faculty of Pharmacy, Department of Biochemistry, Eskisehir, Turkey
}

\begin{abstract}
Carbonic anhydrase enzyme plays a vital role in metabolic events such as acid-base regulation and respiration. In our research, it is tried to determine the inhibitory influences of the cardiovascular therapeutics esmolol hydrochloride, amiodarone hydrochloride and lidocaine hydrochloride on human erythrocytes carbonic anhydrases (hCA I and II). In accordance with this purpose, carbonic anhydrase isoenzymes were purified from human erythrocytes by using affinity chromatography method. Enzyme purity was checked by SDS-PAGE electrophoresis method. After the carbonic anhydrase enzymes were purified, the inhibitory affects of cardiovascular therapeutics on these enzymes, using esterase activity, which is the method of measuring in vitro activity, were examined. The three cardiovascular therapeutics dose-dependently decreased activity of hCAs. $\mathrm{IC}_{50}$ values of amiodarone hydrochloride, esmolol hydrochloride and lidocaine hydrochloride were found to be, respectively, $0.91 \mathrm{mM}, 5 \mathrm{mM}, 5.8 \mathrm{mM}$ for hCA-I and $0.41 \mathrm{mM}, 3.5 \mathrm{mM}$, and $6.36 \mathrm{mM}$ for hCA-II. Our results proved that, under in vitro conditions, cardiovascular therapeutics significantly inhibit human CA-I and II activities. So, irregular use of these medicines may cause serious adverse effects in terms of human health.
\end{abstract}

Keywords: Carbonic Anhydrase, Cardiovascular Therapeutics, Enzyme Inhibition.

\section{İnsan Eritrosit Karbonik Anhidraz İzoenzimleri Üzerine Bazı Kardiyovasküler Terapötiklerin İnhibisyon Etkilerinin İncelenmesi}

\begin{abstract}
$\ddot{\mathbf{O} z}$
Karbonik anhidraz enzimi, asit-baz düzenlemesi ve solunum gibi metabolik olaylarda hayati rol oynar. $\mathrm{Bu}$ çalışmada, bazı kardiyovasküler terapötiklerin (esmolol hidroklorür, amiodaron hidroklorür, lidokain hidroklorür) insan eritrositleri karbonik anhidraz I ve II izoenzimleri (hCA-I ve hCA-II) aktiviteleri üzerine inhibisyon etkilerinin belirlenmesi amaçlanmıştır. Bu amaçla, insan eritrositlerinden afinite kromatografisi yardımıyla karbonik anhidraz izoenzimleri (CA-I ve CA-II) saflaştırıldı. Enzim saflıkları SDS-PAGE ile kontrol edildi. Saflaştırmadan sonra, kardiyovasküler terapötiklerin hCA-I ve hCA-II aktivitesi üzerindeki inhibitör etkileri, in vitro olarak esteraz yöntemi kullanılarak farklı ilaç konsantrasyonlarında belirlendi. Üç kardiyovasküler terapötik doza bağımlı olarak enzim aktivitelerini azalttı. Amiodaron hidroklorür, esmolol hidroklorür ve lidokain hidroklorür'ün $\mathrm{IC}_{50}$ değerleri hCA-I için sırasıyla $0.91 \mathrm{mM}, 5 \mathrm{mM}, 5.8 \mathrm{mM}$ olarak, hCA-II için sirasıyla $0.41 \mathrm{mM}$, $3.5 \mathrm{mM}, 6.36 \mathrm{mM}$ olarak bulundu. Bulgularımız, kardiyovasküler terapötiklerin in vitro koşullarda hCA-I ve hCAII aktivitesini önemli ölçüde inhibe ettiğini göstermektedir. Bu nedenle, bu ilaçların kontrolsüz kullanımı insan sağlığı için ciddi yan etkilere neden olabilir.
\end{abstract}

Anahtar Kelimeler: Enzim İnhibisyonu, Karbonik Anhidraz, Kardiyovasküler Terapötikler.

*Sorumlu yazar: namik.kilinc@igdir.edu.tr

Geliş Tarihi: 22/10./2017 Kabul Tarihi: 25/01/2018 


\section{Introduction}

Carbonic anhydrases (EC 4.2.1.1) are one of the most critical enzymes of the biological compositions and this enzyme contains a zinc metal ion in its active center. CAs catalyze the interconversion of $\mathrm{CO}_{2}$ to bicarbonate $\left(\mathrm{HCO}_{3}{ }^{-}\right)$ion. In addition to, carbonic anhydrase involved in very different physiological procedures like $\mathrm{pH}$ and carbon dioxide homeostasis, biosynthetic reactions (such as lipogenesis, ureagenesis, and gluconeogenesis) and pathological processes like tumor growth and calcification $[1,2]$.

Sixteen isoenzymes of carbonic anhydrase has been detected up to now in animal kingdom. These isoenzymes indicate a difference in terms of their catalytic activity, subcellular localization and sensitivity to varied classes of activators and inhibitors [3]. CA-I and CA-II are cytosolic isozymes and they are abundant amounts of erythrocytes. The most important function of these isoenzymes is in the respiration by catalyzing the metabolism product, the $\mathrm{CO}_{2}$ molecule, the reaction of $\mathrm{HCO}_{3}{ }^{-}$in the tissue capillaries, and the conversion of $\mathrm{HCO}_{3}{ }^{-}$into $\mathrm{CO}_{2}$ in the pulmonary capillaries. CA II isoenzyme is the most studied isoenzyme which has the highest turnover number in CAs [4]. CA-II plays a role in primer transport of sodium to the eye and it helps to regulate the intraocular pressure [5]. In addition to its physiological functions, the literature also mentions that CA-II is associated with cancer. CA-II isoenzymes are responsible for regulating the $\mathrm{pH}$ balance between the cancer cells and the microenvironment. [6]. In vitro cell culture, which resembles the conditions of cancer cell microenvironment, has been shown to increase CA-II expression in endothelial cells [7]. Yoshira and colleagues as shown in their research that CA-II is expressed in endothelial tumor vasculature of lung, renal, esophageal, and melanoma cancers [8]. It is also reported by Parkkila et al. that CA-II can be used as a biomarker in gastrointestinal stromal tumors [9]. Due to all these functions, CAs are vital in metabolism and it is very important to know the inhibitors of carbonic anhydrase isoenzymes for biomedical applications.

In this research, it is examined the in vitro inhibitory affects of cardiovascular therapeutics esmolol hydrochloride, amiodarone hydrochloride and lidocaine hydrochloride on the activities of human erythrocyte carbonic anhydrases. Esmolol hydrochloride is a cardioselective agent that blocks the $\beta_{1}$ adrenergic receptor. It's commonly used in the treatment of ventricular and supraventricular arrhythmias, which are frequently used in emergencies [10]. Amiodarone hydrochloride is an antiarrhythmic drug. It has been used in treating of diverse irregular heartbeats [11]. Lidocaine hydrochloride exerts an antiarrhythmic effect. It has been used to treat ventricular tachycardia. In addition to, it can be used for nerve blocks [12].

Consequently, carbonic anhydrases (CA-I and II) were purified in one-step from human erythrocytes and studied in vitro inhibitory effects of esmolol hydrochloride, amiodarone hydrochloride, lidocaine hydrochloride (Figure 1) on these important isoenzymes. It has been found that hCA I and II enzyme activities are reduced at very low concentrations of the above mentioned medicines.

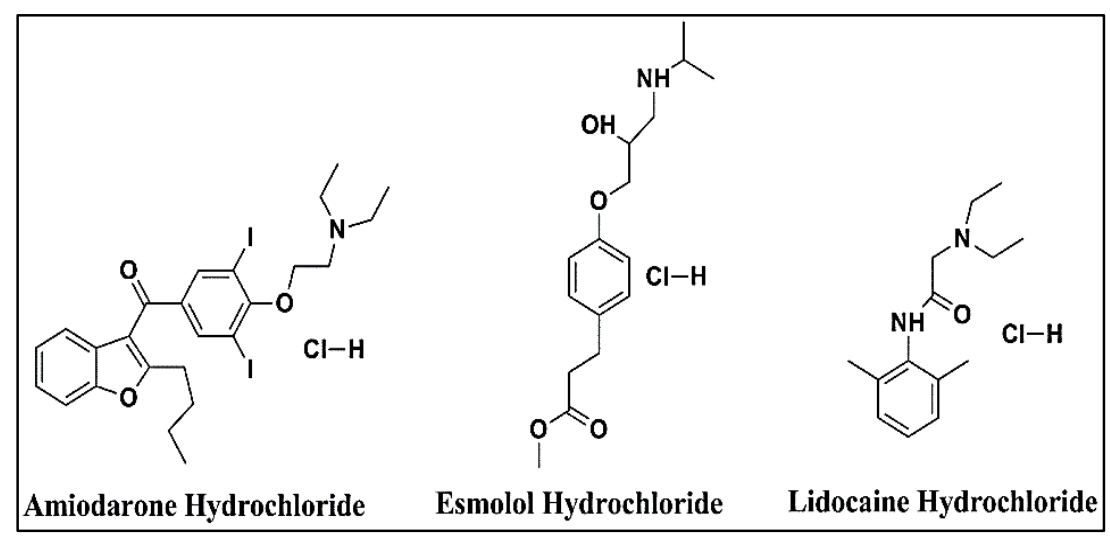

Figure 1. Cardiovascular therapeutics' molecular structures used in this research 


\section{Materials and Methods}

Para-aminobenzene sulfonamide and L-tyrosine were provided by E. Merck (Merck KGaA, Darmstadt, Germany). Protein assay reagents, electrophoresis chemicals and activated with CNBr Sepharose 4B were provided by Sigma- Aldrich Co. All other chemicals used in our study were provided from SigmaAldrich or Merck companies. Esmolol hydrochloride, amiodarone hydrochloride, lidocaine hydrochloride were purchased from a local pharmacy.

\subsection{Enzyme activity method of carbonic anhydrase}

The measurement of the activity of the carbonic anhydrase isoenzymes can be tested in two different in vitro methods:

Hydratase activity method

The hydratase activity based on the computation of physiological activity of the carbonic anhydrase enzyme is one of the measurement methods of the carbonic anhydrase enzyme activity. As Wilbur and Anderson reported the hydratase activity method was performed [13]. The hydratase activity values were computed as the enzyme unit (EU) using the $(\mathrm{t} 0-\mathrm{tc}) / \mathrm{tc}$ equation. $(\mathrm{t} 0=$ the time change in $\mathrm{pH}$ of the non-enzymatic reaction, $\mathrm{tc}=$ the time change in $\mathrm{pH}$ of the enzymatic reaction.) We used this activity measurement method during all the purification procedures.

Esterase activity method

The esterase activity based on the monitoring of the absorbance differences on the conversion between 4-nitrophenyl acetate and the 4-nitrophenolate ion was used to measure the in vitro activity of carbonic anhydrase enzyme [14].

\subsection{Purification of human erythrocyte carbonic anhydrase isozymes through affinity chromatography}

The purification procedures of the CAI and CAII isozymes were performed by the Sepharose-4B Ltyrosine sulfanilamide affinity chromatography column as in our previous work [15].

\subsection{Determination of Protein}

The amount of protein in all purification procedures were detected using a spectrophotometer at $595 \mathrm{~nm}$ wavelength as stated in the Bradford procedure where bovine serum albumin protein was used as a standard protein [16].

\subsection{SDS-polyacrylamide gel electrophoresis}

The purity of the isoenzymes was checked using the SDS-PAGE procedure using gels prepared in two different acrylamide concentrations, $3 \%$ to running gel and $8 \%$ to stacking gel, as reported by Laemmli [17].

\subsection{In Vitro inhibition studies}

The activities of Carbonic anhydrases were carried out spectrophotometric method which by monitoring the absorbance changes at $348 \mathrm{~nm}$ wavelength. Enzyme inhibition studies utilized esterase activity procedure. 4-nitrophenyl acetate (NPA) was used as the substrate for the carbonic anhydrase enzyme in this method. The inhibition efficacy of amiodarone hydrochloride, esmolol hydrochloride, lidocaine hydrochloride on the activity of pure carbonic anhydrases from human erythrocyte were studied. These studies were carried out by testing three times in five different drug compounds concentrations. 
Percentage of enzyme activity values versus drug concentration graphics was plotted and $\mathrm{IC}_{50}$ values were computed from these curves.

\section{Results}

The carbonic anhydrases (hCA I and hCA II) were purified from human erythrocytes. hCA-I and hCAII isozymes were purified with a yield of $39.5 \%$ and $49.5 \%$ and specific activity of 441.1 and 4411.7 $\mathrm{EU} \mathrm{mg}{ }^{-1}$, respectively using affinity gel chromatography which is a chromatographic method based on selective absorption. The whole purification was about 59.9-fold for hCA-I and 599.4-fold for hCA-II. (Table 1).

Table 1. Human erythrocytes carbonic anhydrases (CA-I and CA-II) purification results

\begin{tabular}{ccccccccc}
$\begin{array}{c}\text { Purification } \\
\text { Steps }\end{array}$ & $\begin{array}{c}\text { Activity } \\
(\mathbf{E U} / \mathbf{m l})\end{array}$ & $\begin{array}{c}\text { Total } \\
\text { Volume } \\
(\mathbf{m l})\end{array}$ & $\begin{array}{c}\text { Protein } \\
\left(\mathbf{m g ~ m}^{-1}\right)\end{array}$ & $\begin{array}{c}\text { Total } \\
\text { Protein } \\
(\mathbf{m g})\end{array}$ & $\begin{array}{c}\text { Total } \\
\text { Activity } \\
(\mathbf{E U})\end{array}$ & $\begin{array}{c}\text { Specific } \\
\text { Activity } \\
\left(\mathbf{E U} \mathbf{~ m g}^{-1}\right)\end{array}$ & $\begin{array}{c}\text { Yield } \\
(\%)\end{array}$ & $\begin{array}{c}\text { Purification } \\
\text { factor }\end{array}$ \\
\hline Hemolysate & 200 & 50 & 27.16 & 1358 & 10000 & 7.36 & 100 & 1 \\
hCA-I & 470 & 8.40 & 1.065 & 8.95 & 3948 & 441.1 & 39.5 & 59.9 \\
& & & & & & & & \\
hCA-II & 825 & 6 & 0.187 & 1.122 & 4950 & 4411.7 & 49.5 & 599.4 \\
\hline
\end{tabular}

Using affinity chromatography each purified isoenzyme gave a single band in SDS-PAGE (Figure 2).

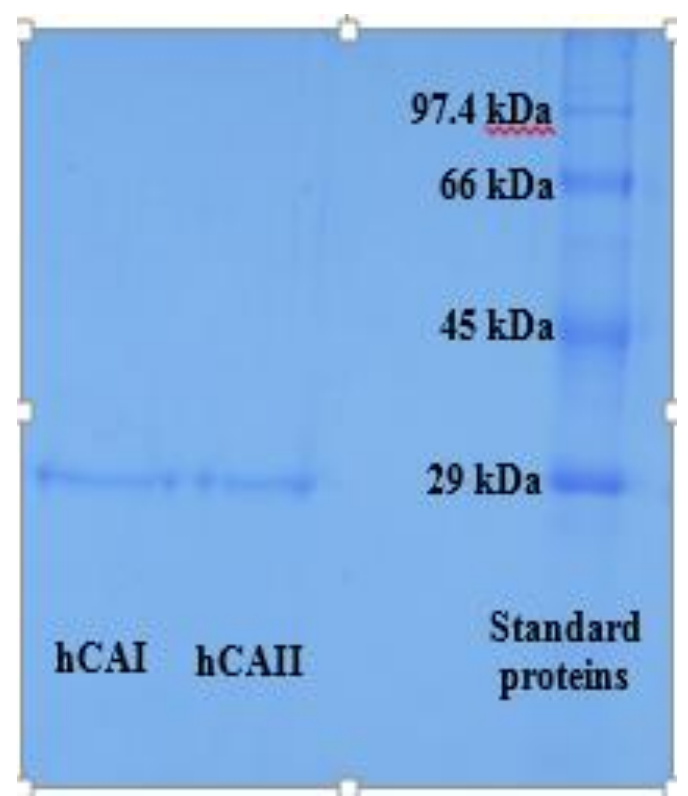

Figure 2. The results of purified erythrocyte hCA-I and hCA-II with SDS-PAGE

Inhibition studies were performed with this purified enzyme. The inhibitory affects of certain cardiovascular therapeutics (amiodarone hydrochloride, esmolol hydrochloride, lidocaine hydrochloride) on these in vitro enzyme activities were assayed and $\mathrm{IC}_{50}$ values were calculated using activity\%-[inhibitor] graphics (Figure 3 and Figure 4). 


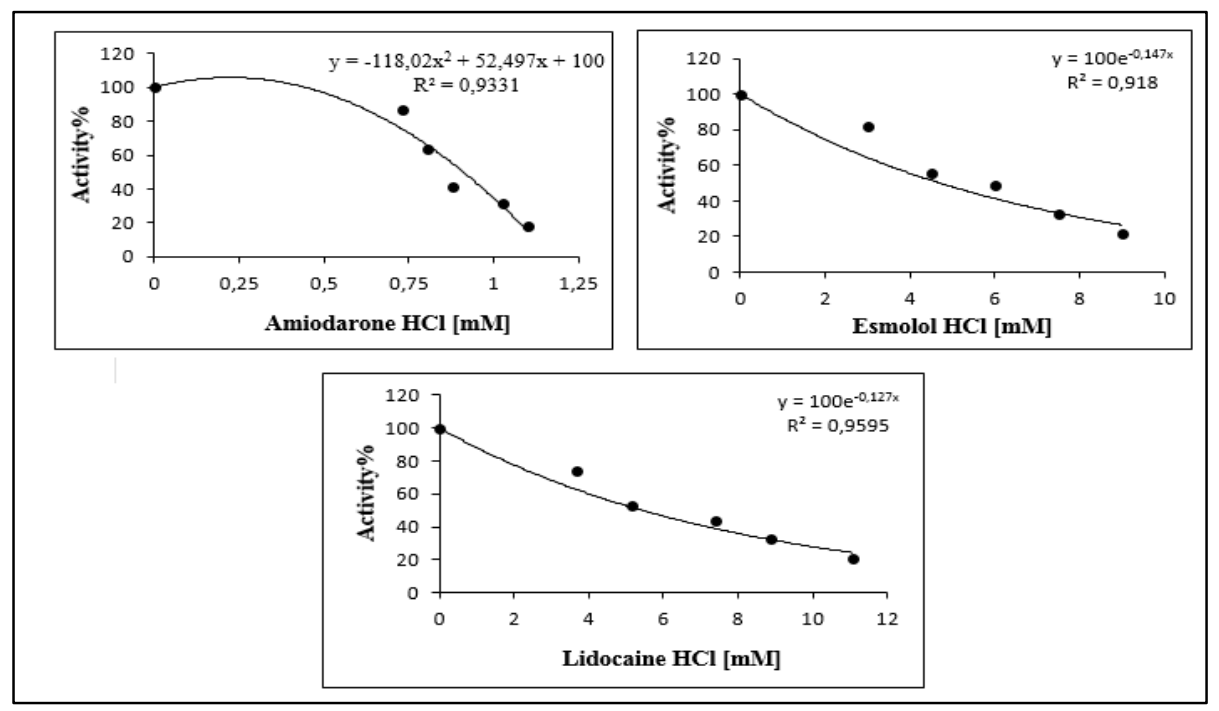

Figure 3 Graphics of activity\% versus drug concentration for hCA-I at different drug concentrations.

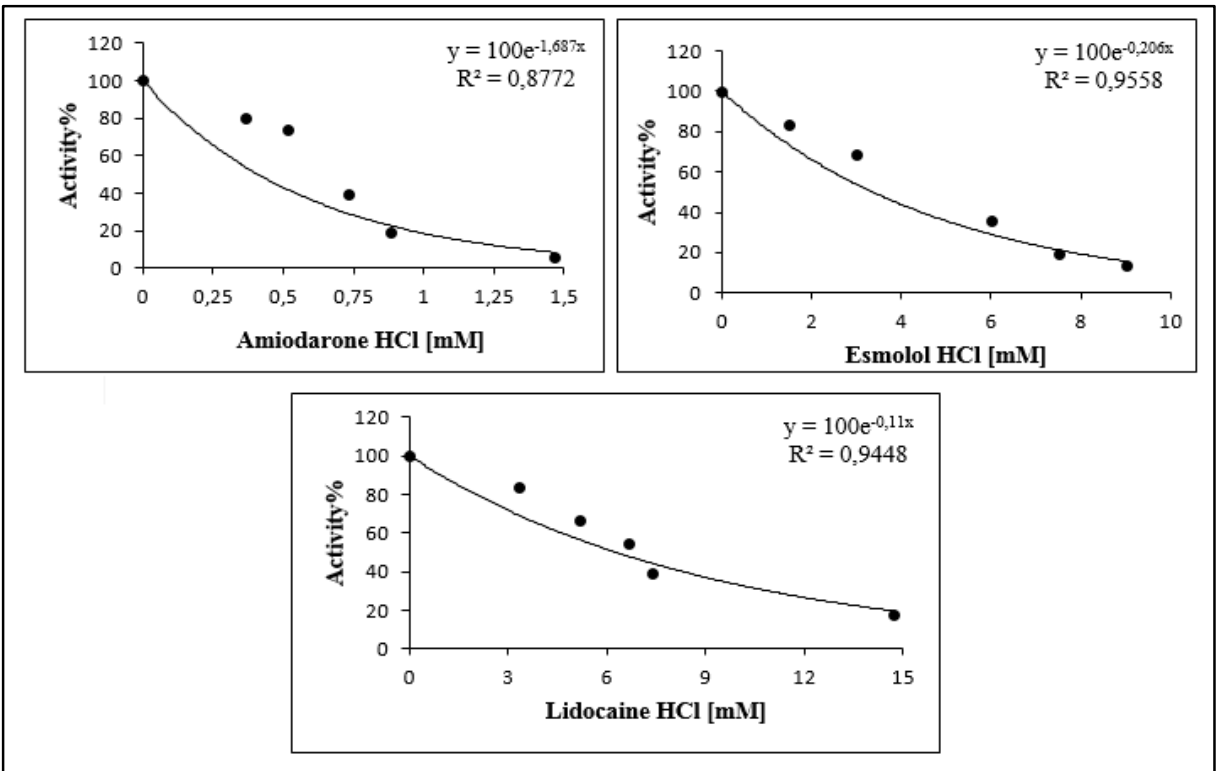

Figure 4. Graphics of activity\% versus drug concentration for hCA-II at different drug concentrations

$\mathrm{IC}_{50}$ values of amiodarone hydrochloride, esmolol hydrochloride and lidocaine hydrochloride for hCAI were determined as $0.91 \mathrm{mM}, 5 \mathrm{mM}, 5.8 \mathrm{mM}$, respectively. $\mathrm{IC}_{50}$ values of amiodarone hydrochloride, esmolol hydrochloride and lidocaine hydrochloride for hCA-II were determined as $0.41 \mathrm{mM}, 3.5 \mathrm{mM}$, $6.36 \mathrm{mM}$, respectively (Table 2).

Table 2. $\mathrm{IC}_{50}$ values for amiodarone hydrochloride, esmolol hydrochloride and lidocaine hydrochloride.

$$
\begin{array}{cc}
\begin{array}{c}
\text { Esterase Activity of } \\
\text { hCA-I }
\end{array} & \begin{array}{c}
\text { Esterase Activity of } \\
\text { hCA-II }
\end{array}
\end{array}
$$

Cardiovascular Therapeutics

$$
I C_{50} \quad I C_{50}
$$

\begin{tabular}{ccc}
\hline Amiodarone Hydrochloride & $0.91 \mathrm{mM}$ & $0.41 \mathrm{mM}$ \\
\hline Esmolol Hydrochloride & $5 \mathrm{mM}$ & $3.5 \mathrm{mM}$ \\
\hline Lidocaine Hydrochloride & $5.8 \mathrm{mM}$ & $6.36 \mathrm{mM}$ \\
\hline
\end{tabular}




\section{Discussion and Conclusion}

The importance of CA inhibitors in the treatment and diagnosis of diseases has been revealed as a result of inhibition studies on CA enzyme for the treatment of glaucoma disease. In these studies, besides clarification of catalytic mechanisms of CA enzyme, the distribution of this enzyme to tissues and the vital functions in these tissues are understood. As a result of, the synthesis of inhibitors and activators of the CA enzyme has been accelerated. Up to now, various inhibitors of CAs have been synthesized and some of them have been used as a drug in the treatment of different diseases like cancer, glaucoma, epilepsy and other neurological illness [18].

Various studies have now been carried out on the basis of many of the diseases in which the activities of some proteins increase and the activities of these proteins have to be selectively stopped by certain chemical substances. On the other hand, it is crucial to investigate the side effects of drugs used in the treatment of many diseases. Because drugs and chemical substances show their effects on metabolism through enzymes. That is, they stop or enhance the activity of a particular enzyme. Therefore, knowing these effects of molecules is very important for drug design studies $[18,19,20]$.

In presented research, it was objected to define the inhibitory effects of some cardiovascular therapeutics on carbonic anhydrase I and II isoenzymes which purified from human erythrocytes. In accordance with this purpose, hCA-I and hCA-II enzymes were purified by using Sepharose-4B-L tyrosine-sulfanilamide affinity gel chromatography. hCA-I and hCA-II isozymes were purified with yield of $39.5 \%$ and $49.5 \%$ and specific activity of 441.1 and $4411.7 \mathrm{EU} \mathrm{mg}^{-1}$, respectively using affinity gel chromatography which is a chromatographic method based on selective absorption. The aggregate purification values were approximately 59.9-fold for hCA-I and 599.4-fold for hCA-II. Additionally, purities of the isoenzymes were controlled using SDS-PAGE. Purified hCA-I and hCA-II isoenzymes showed a single band at 29 $\mathrm{kDa}$ on the SDS-PAGE gel (Figure 1). Afterwards all purification steps, the in vitro inhibitory affects of cardiovascular therapeutics (Amiodarone hydrochloride, esmolol hydrochloride, lidocaine hydrochloride) on hCAs activities were designated at different drug concentrations using the esterase method. One of the reactions that do not occur in the physiological environment is esterase activity, which is catalyzed by the Carbonic Anhydrase enzyme. The esterase activity method basis for the hydrolysis of p-nitrophenyl acetate by carbonic anhydrase enzyme. The formed p-nitrophenol is ascertained spectrophotometrically by light absorption at $340 \mathrm{~nm}$. [14].

Thus, amiodarone hydrochloride, esmolol hydrochloride, and lidocaine hydrochloride showed inhibitory influences on esterase activities of hCA-I and hCA-II. The inhibition values of the enzymes are designated by calculating $\mathrm{IC}_{50}$. In our presented study, $\mathrm{IC}_{50}$ values of amiodarone hydrochloride, esmolol hydrochloride and lidocaine hydrochloride from drug compounds concentration versus activity\% regression analysis graphics showed millimolar levels for hCA-I and hCA-II isozymes. $\mathrm{IC}_{50}$ values of amiodarone hydrochloride, esmolol hydrochloride and lidocaine hydrochloride for hCA-I were determined as $0.91 \mathrm{mM}, 5 \mathrm{mM}, 5.8 \mathrm{mM}$, respectively. $\mathrm{IC}_{50}$ values of amiodarone hydrochloride, esmolol hydrochloride and lidocaine hydrochloride for hCA-II were determined as $0.41 \mathrm{mM}, 3.5 \mathrm{mM}, 6.36 \mathrm{mM}$, respectively. It is clear from these results that each of these three drugs is an effective inhibitor of the human CA isoenzymes. Nevertheless, amiodarone hydrochloride was show more efficient inhibition effect on each carbonic anhydrase isoenzymes compared with esmolol hydrochloride and lidocaine hydrochloride. In our previous study, tenoxicam, fluorometholone acetate and dexamethasone, which are anti-inflammatory agents, effectively inhibited carbonic anhydrase I and II enzymes. In the mentioned study, $\mathrm{IC}_{50}$ values of tenoxicam, fluorometholone acetate, and dexamethasone were found to be for the CA I enzyme $0.198,2.18$ and $11.7 \mu \mathrm{M}$, and for the CA II enzyme $0.11,17.5$ and $14 \mu \mathrm{M}$, respectively [15]. In another study, the inhibitory effects of ceftriaxone sodium, imipenem, and ornidazole drugs on the CA-I and CA-II isoenzymes purified from human erythrocytes were investigated and the $\mathrm{IC}_{50}$ values for CA-I were found to be $1.9,0.0081$ and $0.318 \mathrm{mM}$ and $2.542,0.0258$ and 0.343 $\mathrm{mM}$ for CA-II, respectively [3]. It is clear from these results, besides the drug compounds mentioned 
above, amiodarone hydrochloride, esmolol hydrochloride, and lidocaine hydrochloride compounds are also quite effective CA-I and CA-II inhibitors.

Consequently, the hCA-I and hCA-II isozymes that isolated from human erythrocytes were purified in a single step with a very high specific activity. Amiodarone hydrochloride, esmolol hydrochloride, and lidocaine hydrochloride indicated inhibitory influences on these enzyme activities at quite low concentrations. Unlike esmolol hydrochloride and lidocaine hydrochloride, amiodarone hydrochloride showed a very strong inhibitory effect. The Inhibition of some enzymes that occur in tissues can lead to many disorders. Because of carbonic anhydrase role in vital metabolic events such as acid-base regulation and respiration, the inhibitory affect on the hCA-I and hCA-II activity of these cardiovascular therapeutics can cause harmful consequences for human health.

\section{References}

1. Supuran C.T. 2008. Carbonic Anhydrases: Novel Therapeutic Applications for Inhibitors and Activators, Nature Reviews Drug Discovery, 7(2): 168-181.

2. Temperini C., Innocenti A., Scozzafava A., Parkkila S., Supuran C.T. 2010. The Coumarin-binding Site in Carbonic Anhydrase Accommodates Structurally Diverse Inhibitors: The Antiepileptic Lacosamide As an Example and Lead Molecule for Novel Classes of Carbonic Anhydrase Inhibitors, Journal of Medicinal Chemistry, 53(2): 850-854.

3. Ekinci D., Beydemir S., Alim Z. 2007. Some Drugs Inhibit In Vitro Hydratase and Esterase Activities of Human Carbonic Anhydrase-I and II, Pharmacological Reports, 59(5): 580-587.

4. Ekinci D., Al-Rashida M., Abbas G., Senturk M., Supuran C.T. 2012. Chromone Containing Sulfonamides as Potent Carbonic Anhydrase Inhibitors, Journal of Enzyme Inhibition and Medicinal Chemistry, 27(5): 744-747.

5. Ridderstrale Y., Wistrand P.J., William F.B. 1994. Membrane-associated CA Activity in The Eye of The CA II-Deficient Mouse, Investigative Ophthalmology \& Visual Science, 35(5): 2577-2584.

6. Parkkila S., Rajaniemi H., Parkkila A.K., Kivela J., Waheed A., Pastoreková S., Pastorek J., Sly W.S. 2000. Carbonic Anhydrase Inhibitor Suppresses Invasion of Renal Cancer Cells In-Vitro, Proceedings of the National Academy of Sciences, 97(5): 2220-2224.

7. Hynninen P., Parkkila S., Huhtala H., Pastorekova S., Pastorek J., Waheed A., Sly W.S., Tomas E. 2012. Carbonic Anhydrase Isozymes II, IX, And XII in Uterine Tumors, APMIS, 120(2): 117-129.

8. Yoshiura K., Nakaoka T., Nishishita T., Sato K., Yamamoto A., Shimada S., Saida T., Kawakami Y., Takahashi T.A., Fukuda H., Imajoh-Ohmi S., Oyaizu N., Yamashita N. 2005. Carbonic Anhydrase II is a Tumor Vessel Endothelium-associated Antigen Targeted by Dendritic Cell Therapy, Clinical Cancer Research, 11(22): 8201-8207.

9. Parkkila S., Lasota J., Fletcher J.A., Ou W.B., Kivelä A.J., Nuorva K., Parkkila A., Ollikainen J., Sly W.S., Waheed A., Pastorekova S., Pastorek J., Isola J., Miettinen M. 2010. Carbonic Anhydrase II. A Novel Biomarker for Gastrointestinal Stromal Tumors, Modern Pathology, 23 (5): 743-50.

10. Desmond J., Steven S., Edward M. 1993. Esmolol Hydrochloride, Sodium Nitroprusside, and Isoflurane Differ in Their Ability to Alter Peripheral Sympathetic Responses, Anesthesia \& Analgesia, 77(2): 281-290.

11. Swan J.H., Chisholm A.W. 1976. Control of Recurrent Supraventricular Tachycardia with Amiodarone Hydrochloride, Canadian Medical Association Journal, 114(1): 43-44.

12. Claffey E., Reader A., Nusstein J., Beck M., Weaver J. 2004. Anesthetic Efficacy of Articaine for Inferior Alveolar Nerve Blocks in Patients with Irreversible Pulpitis, Journal of Endodontics, 30 (8): 568-571. 
13. Wilbur K.M., Anderson N.G. 1948. Electrometric and Colorimetric Determination of Carbonic Anhydrase, Journal of Biological Chemistry, 176 (1): 147-154.

14. Verpoorte J.A., Mehta S., Edsall J.T. 1967. Esterase Activities of Human Carbonic Anhydrases B And C, Journal of Biological Chemistry, 242(18): 4221-4229.

15. Alim Z., Kilinc N., Isgor M.M., Sengul B., Beydemir S. 2015. Some Anti-inflammatory Agents Inhibit Esterase Activities of Human Carbonic Anhydrase Isoforms I and II: An In Vitro Study, Chemical Biology \& Drug Design, 86 (4): 857-863.

16. Bradford M.M. 1976. A Rapid and Sensitive Method for The Quantitation of Microgram Quantities of Protein Utilizing The Principle of Protein-dye Binding, Analytical Biochemistry, 72(1-2): 248251.

17. Laemmli U.K. 1970. Cleavage of Structural Proteins During The Assembly of The Head of Bacteriophage T4, Nature, 227(5259): 680-685.

18. Alim Z., Beydemir S. 2016. Some Anticancer Agents Act on Human Serum Paraoxonase-1 to Reduce Its Activity, Chemical Biology \& Drug Design, 88(2): 188-196.

19. Sen E., Alım Z., Duran H., İsgör M.M., Beydemir S., Kasımogulları R., Ok S. 2013. Inhibitory Effect of Novel Pyrazole Carboxamide Derivatives on Human Carbonic Anhydrase Enzyme, Journal of Enzyme Inhibition and Medicinal Chemistry, 28(2): 328-336.

20. Ekinci D., Beydemir S. 2009. Effect of Some Analgesics on Paraoxonase-1 Purified from Human Serum, Journal of Enzyme Inhibition and Medicinal Chemistry, 24(4): 1034-1039. 